\title{
FACTS CONCERNING THE COUNTERACTION OF MILITARY NEGOTIATING PARTNERS, FASTIDIOUS AND UNFAIR, IN CRISIS SITUATIONS AND WAR TIME
}

\author{
Mircea VLADU, Stelian POPESCU, Ioan Dan POPA, Florin ILIE \\ "Nicolae Bălcescu" Land Forces Academy, Sibiu, Romania \\ vladumircea57@yahoo.com, fam_popes@yahoo.com, \\ paragon1971@gmail.com, ilieflorinv@yahoo.com
}

\begin{abstract}
The applications highlighted the fact that, in crisis situations and war time, there were military negotiations, in which the partners have proven their unfairness and stiffness. The inflexibility and unfairness of the negotiator resides in the fact that he used incorrect tactics [1], especially subterfuges, for obtaining advantages. About this negotiating partner we would like to have the following discussion.
\end{abstract}

Keywords: military negotiation, crisis, war, negotiating partner

\section{Introduction}

Experience proved that any organization can face serious crisis operations and that, regardless of the security measures taken, the crisis can get out of control if it is not managed properly. From this perspective, the military organization authorized to defend the independence, sovereignty and integrity of the state it represents, can incur crisis or conflict situations, and if these attributes are endangered by the actions of at least one aggressor. The Management of Crisis or War Situations can be achieved by negotiations and if they fail, by armed conflict, also followed by negotiations, but in advantageous conditions for the winner and disadvantageous for the loosing part. The experience in crisis management and war time proved that planning and the negotiations between belligerents, no matter how difficult they might have been, have been and still are the method preferred to avoid a conflict burst, which will inevitably lead to serious human losses, and also serious material losses which can prove, in many of the cases, immeasurable. Starting from this experience, we consider that especially in the military field, negotiations in crisis situations or in war time should be much more important than hearing the sound of weapons, since wisdom has always been more powerful than actual force. The most important thing is that negotiation must be planned and be in progress at the right time, by skilful negotiators, capable to fulfill the objectives including the situations where at the negotiation table the partners tend to be fastidious, incorrect and avoid telling the truth by telling lies, being convinced that a repeated lie will eventually become a truth, or know how to act properly in order to manipulate the interlocutors. An essential task of a successful military negotiation takes into account the identification and counteraction of fastidious and incorrect negotiation partners. In order to achieve this, we will further present the types of difficult and incorrect military negotiation partners and also some techniques to negotiate with them. 


\section{Types of stiff and incorrect negotiation partners:}

The history of military negotiations in crisis situations and war time proved that there are stiff and incorrect negotiating partners, as follows:

a) lying negotiating partners;

b) negotiating partners that avoid direct answers;

c) negotiating partners that promote manipulation for bad intentions;

d) negotiating partners that quote and make false assumptions;

e) negotiating partners who are both offensive and defensive in attitude.

The lying negotiating partners are characterized by being overly talkative, using an abundant amount of words that are said very fast, over a relatively long period of time. The "chit-chat" can be a sign of a mental disorder, like maniacal behaviour.

The procedure for counteracting a lying negotiating partner must contain [1]:

a) addressing a high number of questions and carefully listening to the answers given, which, in most cases are contradictory, because the lying negotiator usually does not have the answers prepared, but here lies on his intuition, which, most often may be wrong, as he is not paying attention to the previous answers, therefore being in contradiction in his speech;

b) carefully study his posture, the position of his palms and notice the fact that the lying negotiating partner has uncontrolled and forced finger gestures, and his eyes are not in contact with the speaker but somewhere else or looking downwardsavoiding the speaker's eyes and focusing too much on the answer. At short periods of time, he regularly touches his nose, scratching it, as if resisting an unbearable itching.

All these attitudes reveal the true face of a lying negotiating partner, who should be immediately told to leave the negotiation table, since he is untrustworthy and unconvincing.

The reaction of the exposed lying negotiating partner may be violent, therefore, before telling him about the decision to be eliminated from the negotiation, security personnel should be present nearby who is prepared to intervene and take him out of the room before any physical action occurs.

Negotiating partners that avoid direct answer especially when the partners discuss key elements of the negotiation belong to the individuals who are over talkative[1], for they avoid to answer directly in order to annoy the interlocutor and direct him out of desired purposes. The excitement of military negotiating interlocutor can increase so much that he can have serious problems in remembering the content of the question, and sometimes the actual flow of the entire negotiation.

In order to avoid such a situation, the interlocutor must not lose his temper, but keep a steady and clear mind, trying by inference to control the situation or problem which the negotiating partner is mostly interested in getting away with, by avoiding to give the answer. There are situations in which, in order to establish the issue or the objective for which the negotiation partner is trying to avoid the answer, requires a longer time. It is important that the during that time, the negotiating partner asks his interlocutor a lot of questions, until he gives up and gives the expected answer.

Negotiating partners that promote manipulation for bad intentions are usually present in every types of negotiation, but excel especially in the military negotiations because the desire and tendency to influence other interlocutors are so big that negotiations can alter security, sovereignty, independence and integrity of the state, with dramatic repercussions over the future of the nation.

For misleading the interlocutor, the negotiating partner that promotesillintended manipulation, uses any kind of manipulation he desires at that moment, both in a negative or positive way of manipulating. Promoting the positive way of manipulation, the negotiating partner wants only to deceive or to convince the 
interlocutor about his good intentions and make him believe that he is an honest negotiating partner. If he has accomplished his purpose, the negotiating partner will continue to use the negative manipulation, namely the malevolent one. Going on with this type of manipulation depends on the interlocutor's ability to notice the true meaning of the manipulation and discern if he could get some advantages from this situation. If not, the interlocutor should not be influenced by ill-intended manipulation, but he must act rapidly to change the tactics of negotiation, in order to fulfill the tasks he was assigned with.

The negotiating partners that quote and make false statements are the merciless negotiators, capable to make the interlocutors say things they have never said before[1]. The rudeness of this kind of negotiator is so big that they make allegations about the interlocutor, trying to make him believe that he is the one responsible for the respective issue.

For redirecting the military negotiations on the right path, the speaker must convince this type of negotiating partner that the allegations are not real, and for continuing the negotiation process the respective negotiating partner must abandon this type of approach, otherwise the negotiation is bound to fail.

Negotiating partners who have both an offensive and a defensive behaviour can be extremely difficult during the negotiation process [5].

Negotiating partners who try to defend themselves have an inflexible behaviour, are skeptical, suspicious, revengeful etc. They may only negotiate when they are absolutely convinced that both competitors in the negotiation will win. The fact that they consider the negotiating process would not bring them anything good, can make the speaker's job extremely difficult, and going on with the process depends on its success.

Also stiff are the ones that rely exclusively and excessively on an offensive action, being convinced that the interlocutors must fear them during the negotiating process, so they can eventually fulfill their objectives. Their offensive attitude clearly demonstrates the desire to dominate the interlocutors and turn the negotiation in their favour. Moreover, it should be pointed out the fact that the interlocutors cannot be easily tricked and they struggle not to act by the rules of this type of negotiating partners.

\section{Considerations regarding the procedures for negotiating with stiff and unfair military negotiating partners}

The literature has in its composition two main procedures of how to negotiate with stiff and unfair partners, namely [2]:

a) the procedure of closing the negotiation without results;

b) the procedure of continuing the negotiation and obtaining some advantages; We consider that besides the ones we have mentioned above, there are two more:

a) the procedure of negotiation from the winning position, which highlights the fact that the loser cannot negotiate from an equal position with the winner, especially when the loser is responsible for igniting the aggression; a good example in this matter is the negotiation attempt after the German surrender, in the Second World War, when the outstanding leaders of the fascist Germany who were accused of war crimes and genocide have been executed by hanging.

b) the negotiating procedure from the losing position concerns the fact that the loser tries to negotiate with the winner from an equal position, knowing that the loser is not responsible for the aggression; one relevant example is the end of the war between Dacia and the Roman Empire (101-102), when the Dacians, even though they were defeated, they negotiated a favourable peace treaty for them and humiliating for the Romans, which did not happen again at the end of the second war between Dacians and Romans (105-106).

Regardless of the type of negotiating procedure adopted, a set of rules must be followed, such as[2]: 
a) permanent focus on the purposes of the military negotiation; their achievement is the reason of both the winner's and the loser's satisfaction; therefore, situations in which negotiation might be shortened should be avoided;

b) surprising the negotiating partner by the conduct, ability, the art and science of communication and compliance etc.; while the negotiating partner is left talking, the interlocutor is trying to empathize with the partner, to identify the interests and purposes desired, also the reasons for which he is reacting that way and suddenly ask him questions to find the real reasons of his intensions and purposes;

c) respecting the different opinions of the interlocutors, but brining arguments to prove that they are wrong; the phrase "I respect your argument, but I cannot agree with...because...";

d) preventing a possible failure of the military negotiation; even though history has recorded over time several failures during the military negotiations, in order to prevent losses during military campaigns, it is necessary that military negotiators make serious efforts so that the negotiation does not end in a failure;

e) avoiding threats during the military negotiations, but using them in case a possible failure might occur; under these circumstances, it may be emphasized, according to some participants in the negotiation, the tense negotiation between the Albanian ethnic leaders and peace keeping forces during the "Alba Operation" - high tensions due to some weapons that were put on the table by both parties during the negotiations;

\section{Conclusions}

The military negotiation is one of the most complex types of negotiations described in the specialized literature. The complexity resides in the conditions of planning, preparing and unfolding of the process, also in the level of ambition of the partners, be they winners or losers.

The experience recorded during the military negotiations pointed out that at the negotiation participates, besides the partners with good intentions, some stiff and unfair partners, who hinder the progress of the negotiating process.

It is important that the types of negotiating partners who are stiff and unfair are identified and their attitude neutralized, so that the negotiation will carry out according to the procedure, avoiding failure, which is not beneficial for any of the partners.

Moreover, some essential aspects are also important, which should be considered, indicating that a negotiating partner is ready to close the negotiation: approval of the interlocutor's arguments; focusing on the effects caused by closing the deal; repeated questioning about the aspects to be followed next; fugitive looks and repeated touch of the documents during the negotiation; presentation by one of the interlocutors of certain arguments that made the agreement possible; affirmative answers to the questions asked during the negotiation [3].

\section{References}

[1] Prof.univ. dr. MirceaVladu, Comunicarea și negocierea, Editura Burg, Sibiu 2009, p.202.

[2] Prof.univ. dr. MirceaVladu, Comunicarea şi negocierea, Editura Burg, Sibiu 2009, p.204.

[3] Astrid Heeper, Michael Schmidt, Tehnici de negociere, Editura BIC ALL 2007, p.108-109. 